\title{
Comparison of the Antioxidant Activity of Malaysian Ginger (Zingiber officinale Roscoe) Extracts with that of Selected Natural Products and its Effect on the Viability of Myoblast Cells in Culture
}

(Perbandingan Aktiviti Antioksidan Halia (Zingiber officinale Roscoe) Malaysia dengan Produk Semula Jadi Terpilih dan Kesannya terhadap Kebolehidupan Sel Mioblas dalam Kultur

\author{
Nur Fatin Nabilah Mohd Sahardi, Faizul JaAfar, Siti Nor Asyikin ZaKaria, Jen Kit Tan, Mariam \\ FIRDHAUS MAD NORDIN \& SUZANA MAKPOL*
}

\begin{abstract}
Ginger has been proven to possess various therapeutic effects, including antibacterial, anticancer, anti-inflammatory, and antioxidant effects. However, data on the comparison of ginger antioxidant activity with that of other natural products are still lacking. This study aimed to analyse and compare the antioxidant properties of two types of Malaysian ginger extracts (GE1 and GE2) with that of selected natural products. The antioxidant activities were measured by 2,2-diphenyl1-picryl-hydrazyl-hydrate (DPPH) and ferric reducing antioxidant power (FRAP) assays, while cell viability was determined by 3-(4,5-dimethylthiazol-2-yl)-5-(3-carboxymethoxyphenyl)-2-(4-sulfonyl)-2H-tetrazolium (MTS) assay. The order of the DPPH scavenging activities was as follows: vitamin $C>$ palm tocotrienol-rich fraction (TRF) $>$ $\alpha$-tocopherol $>N$-acetylcysteine $(N A C)>$ Ficus deltoidea $>$ butylated hydroxytoluene $(B H T)>$ Centella asiatica $>G E 2$ $>G E 1>$ Moringa oleifera > Kelulut honey; the order of the mean FRAP value was as follows: NAC $>\alpha$-tocopherol $>$ $B H T>T R F>$ Ficus deltoidea $>$ Moringa oleifera $>G E 2=G E 1>$ Centella asiatica $>$ Kelulut honey. The viability assays showed that both ginger extracts significantly increased the percentage of viable cells $(p<0.05)$. In conclusion, neither of the ginger extracts was cytotoxic toward cells and both possessed comparable antioxidant properties, indicating their potential for ameliorating oxidative stress.
\end{abstract}

Keywords: Antioxidant property; gingerol; Malaysian ginger; myoblasts; shogaol

ABSTRAK

Halia telah terbukti mempunyai pelbagai kesan terapeutik termasuklah kesan anti-bakteria, anti-kanser, anti-radang dan antioksidan. Namun sehingga kini, perbandingan aktiviti antioksidan antara halia dengan produk semula jadi yang lain masih lagi kurang. Oleh itu, tujuan kajian ini dijalankan adalah untuk menganalisis dan membandingkan ciri-ciri antioksidan yang ada pada dua jenis ekstrak halia (GE1 dan GE2) yang ada di Malaysia dengan produk semula jadi yang lain. Aktiviti antioksidan telah diukur melalui asai 2,2-difenil-1-fikril-hidrazil-hidra (DPPH) dan asai aktiviti penurunan kuasa antioksidan ion ferik (FRAP), manakala kebolehidupan sel ditentukan melalui asai 3-(4,5-dimetiltiazol2-yil)-5-(3-karboksimetoksifenil)-2-(4-sulfonil)-2H-tetrazolium (MTS). Susunan untuk aktiviti hapus sisa radikal bebas DPPH adalah seperti berikut: vitamin $C>$ fraksi kaya tokotrienol (TRF) $>\alpha$-tokoferol $>N A C>$ Ficus deltoidea $>B H T$ $>$ Centella asiatica $>G E 2>G E 1>$ Moringa oleifera $>$ madu Kelulut, manakala susunan untuk aktiviti penurunan kuasa antioksidan ion ferik (FRAP) adalah seperti berikut: $N A C>\alpha$-tokoferol $>B H T>T R F>$ Ficus deltoidea $>$ Moringa oleifera $>G E 2=G E 1>$ Centella asiatica $>$ madu Kelulut. Asai kebolehidupan sel menunjukkan peratus kebolehidupan sel yang dirawat dengan kedua-dua ekstrak halia meningkat secara signifikan ( $<<0.05)$. Kesimpulannya, kedua-dua jenis ekstrak halia ini tidak memberi kesan toksik terhadap sel dan mengandungi ciri-ciri antioksidan yang berpotensi mengurangkan aras tekanan oksidatif.

Kata kunci: Ciri antioksidan; gingerol; halia Malaysia; mioblas; shogaol 


\section{INTRODUCTION}

Ginger (Zingiber officinale) is a medicinal plant that is derived from one of two species, Zingiber officinale Roscoe and Zingiber officinale Rubrum (Ahmed et al. 2011; Shimoda et al. 2010). Zingiber officinale Roscoe belongs to the family Zingiberaceae, which can be found in subtropical and tropical Asia, Africa, Far East Asia, China, and India (Tanaka et al. 2015). Several bioactive components have been identified in this ginger species, such as 6-gingerol, 6-shogaol, 10-gingerol, gingerdiones, gingerdiols, paradols, 6-dehydrogingerols, 5-acetoxy6-gingerol, 3,5-diacetoxy-6-gingerdioal and 12-gingerol, which contribute to the many biological activities of ginger (Park et al. 2008; Tanaka et al. 2015; Van Breemen et al. 2011). The most abundant active compounds found in fresh ginger are 6-gingerol and 6-shagoal (Jolad et al. 2004; Tanaka et al. 2015).

The bioactive compounds and constituents of ginger have various therapeutic effects, including antibacterial (Chakotiya et al. 2017; Park et al. 2008; Valera et al. 2015) anticancer (Habib et al. 2008; Pashaei-Asl et al. 2017; Saha et al. 2014), anti-inflammatory (Ezzat et al. 2018; Habib et al. 2008), antidiabetic (Al-Amin et al. 2006), gastroprotective (Liju et al. 2015), antioxidant (ShirinAdel \& Prakash 2010; Si et al. 2018), and neuroprotective (Hussein et al. 2017) effects. The antioxidant property of Zingiber officinale Roscoe has been proven to reduce many oxidative stress-related medical conditions, including diabetes, cardiovascular disease (Wang et al. 2017), cancer (Yasmin Anum et al. 2008) and inflammatory disease (Mozaffari-Khosravi et al. 2016). A previous study showed that ginger extract displays strong antioxidant properties and can perform a function similar to that of antioxidant enzymes such as superoxide dismutase (SOD), glutathione peroxidase (GPx) and catalase (CAT), which eliminate superoxide radicals and hydrogen peroxide that can cause oxidative damage to cells (Ahmad et al. 2006). Mahluji et al. (2013) demonstrated that the antioxidant properties of ginger had a positive effect on insulin resistance in type 2 diabetes patients by increasing glucose tolerance and uptake in the body, which caused a decrease in insulin resistance. In addition to its antioxidant properties, ginger also acts synergistically with anti-tuberculosis treatments by decreasing tumour necrosis factor alpha (TNF- $\alpha$ ), lipid peroxidation and malondialdehyde (MDA) in tuberculosis patients (Kulkarni \& Deshpande 2016).

Antioxidant agents play a crucial role in scavenging free radicals and reactive oxygen species (ROS), which are produced by normal biological processes in the body or from exogenous sources (Waris \& Ahsan 2006). The excessive production of ROS contributes to the oxidation of biological molecules such as carbohydrates, DNA, proteins and lipids, resulting in the failure of biological function as well as cellular damage by apoptosis, which later contributes to disease progression (Ramalingam \& Kim 2012; Suzuki et al. 2015). High production of ROS also results in activation of transcriptional factors and kinase enzymes, which can cause an imbalance in protein synthesis and breakdown (Meng \& Yu 2010). The antioxidant properties of ginger are influenced by the extraction and processing method. A study conducted by Rigane et al. (2018) found that methanol extract exhibited a higher anti-radical capacity than ethyl acetate extract. This was in accordance with another study that reported that ethanol extraction of ginger resulted in better antioxidant properties than the water extraction method (Tohma et al. 2017).

In addition to ginger, there are other natural products that have been reported to act as potent antioxidants, including honey, Moringa oleifera, Ficus deltoidea, and Centella asiatica. A previous study showed that Moringa oleifera, which possesses high antioxidant capacity, has the potential to prevent disease caused by oxidative stress (Wright et al. 2017). Moringa oleifera has been shown to possess higher reducing power and to lower free radicals better than five selected vegetables, cabbage, spinach, broccoli, cauliflower, and peas (Pakade et al. 2013). A study performed by Abrahim et al. (2018) showed that Ficus deltoidea also has excellent antioxidant activity without showing any cytotoxic effect on normal liver cells (Abrahim et al. 2018; Misbah et al. 2013). A study on another natural product, Centella asiatica, showed that different extraction solvents demonstrated various degrees of antioxidant potential, which contributed to the differences in pharmacological activity (Rahman et al. 2013). Another natural product, Tualang honey, exhibited the most effective free-radical scavenging activity compared to other types of honey (Kishore et al. 2011). The antioxidant properties of these natural products were reported to be due to the existence of their phenolic content (Abrahim et al. 2018; Ariffin et al. 2011; Kishore et al. 2011; Misbah et al. 2013; Pourreza 2013).

Data on the comparison of the antioxidant properties of ginger with those of other natural products, however, are still lacking. Therefore, the present study aimed to analyse and compare the antioxidant properties of two types of Malaysian ginger extracts with the antioxidant properties of other selected natural products, such as Kelulut honey, Moringa oleifera, Ficus deltoidea, Centella asiatica, tocopherol, and tocotrienol-rich fraction (TRF). The effects of ginger extracts on the viability of myoblast cells in culture were also studied. 


\section{MATERIALS AND METHODS}

\section{GINGER EXTRACT PREPARATION}

Ginger (Zingiber officinale Roscoe) extract was processed by using subcritical water extraction and obtained from Universiti Teknologi Malaysia (UTM, Malaysia). In this study, the extraction procedure was carried out on dried ginger by using two types of extraction methods. For the extraction of ginger extract 1 (GE1), the optimum processing conditions were $130{ }^{\circ} \mathrm{C}$ for $30 \mathrm{~min}$, while the solvent-to-solid ratio was $28 / 2 \mathrm{mLmg}^{-1}$. In the extraction of ginger extract 2 (GE2), the optimum conditions were $120^{\circ} \mathrm{C}$ for $20 \mathrm{~min}$, and the solvent-to-solid ratio was $28 / 2$ $\mathrm{mLmg}^{-1}$. Thus, two types of ginger extracts (GE1 and GE2) were produced and further analysed in this study.

\section{INSTRUMENTATION AND CHROMATOGRAPHIC CONDITIONS}

The analytical method for the detection of 6-gingerol and 6-shogaol was performed by using a Waters Alliance 2695 LC system (USA) connected with a Waters model 2996 photodiode-array detector (USA). Data were collected and processed with the Empower workstation. The optimum UHPLC system consisted of a $\mathrm{C}_{18}$ reversedphase column. Gradient elution was performed with water and acetonitrile at a flow rate of $0.4 \mathrm{mLmin}^{-1}$, and photodiode array (PDA) detection was conducted at 282 $\mathrm{nm}$. Water and $100 \%$ acetonitrile were used as mobile phase $\mathrm{A}$ and mobile phase $\mathrm{B}$, respectively. The separation of the active components of ginger was carried out based on the gradient elution program with water and acetonitrile (Merck, Germany) as follows: from 0 to 15 $\mathrm{min}$, the volumetric ratio was 70:30; from 15 to $16 \mathrm{~min}$, the volumetric ratio was $5.0: 95$; from 16 to $17 \mathrm{~min}$, the volumetric ratio was $5.0: 95 \mathrm{~min}$; from 17 to $20 \mathrm{~min}$, the volumetric ratio was 70:30.

\section{PREPARATION OF NATURAL PRODUCTS FOR THE DPPH AND FRAP ASSAYS}

Stock solutions of Kelulut honey (Droness, Kelantan, Malaysia), Moringa oleifera (Klau Valley, Integrated Farm Sdn. Bhd. Malaysia), standardised extract of Ficus deltoidea (HERbagus Trading, Malaysia), standardised extract of Centella asiatica (Forest Research Institute, Malaysia), $\alpha$-tocopherol (98.9\% pure d-ATF, ChromaDex, USA) and TRF (Sime Darby Bhd., Malaysia) were prepared at a concentration of $\mathrm{mgmL}^{-1}$. Each natural product was weighed and diluted with ultrapure water or ethanol based on its solubility characteristics. Vitamin C (99\% pure L-ascorbic acid, Sigma, USA), NAC ( $>99 \%$ pure $N$-acetyl-L-cysteine, Sigma, USA) and BHT (99\% pure 2,6-di-tert-butyl-4-methylphenol, Sigma, USA) were used as controls. The stock solutions of vitamin C, $\mathrm{N}$-acetylcysteine (NAC) and butylated hydroxytoluene (BHT) were prepared by weighing the materials and diluting them with ultrapure water, $100 \%$ ethanol and $95 \%$ ethanol, respectively, at a concentration of $10 \mathrm{mg} /$ $\mathrm{mL}$. All the controls were used for the quantification of the 2,2-diphenyl-1-picryl-hydrazyl-hydrate (DPPH) free radical scavenging activity.

\section{2,2-DIPHENYL-1-PICRYL-HYDRAZYL-HYDRATE (DPPH) FREE RADICAL SCAVENGING ACTIVITY}

The stock solution of 1,1-diphenyl-2-picryl-hydrazyl (Sigma, USA) was prepared in methanol by mixing 60 $\mathrm{mL}$ methanol (Merck, Germany) with $40 \mathrm{~mL}$ acetate buffer (Merck, Germany) ( $\mathrm{pH}$ 5.5). The ginger extracts GE1 and GE2, the natural product extracts and the controls were diluted at a series of final concentrations of $0,10,20,50,100,200,500$, and $1000 \mu \mathrm{gmL}^{-1}$ with the respective diluents. Then, $0.75 \mathrm{~mL}$ of the diluted extract or control was mixed with $1.5 \mathrm{~mL}$ of $0.009 \mathrm{mgmL}^{-1} \mathrm{DPPH}$ in methanol by using a vortex. The mixture was incubated at room temperature for $10 \mathrm{~min}$. Then, the absorbance was recorded at a wavelength of $517 \mathrm{~nm}$ with an Enspire Multimode Plate Reader (Perkin Elmer, Singapore). Methanol was used as a control $\left(\mathrm{A}_{\mathrm{c}}\right)$. The inhibition percentage was calculated based on the following equation:

$\%$ Inhibition $=\frac{(A c-A s)}{A c} \times 100 \% \quad($ Garcia et al. 2012)

FERRIC REDUCING ANTIOXIDANT POWER (FRAP) ASSAY

The FRAP reagent was prepared by mixing $2.5 \mathrm{~mL}$ of 2,4,6-tri(2-pyridyl)-1,3,5-triazine (TPTZ) solution (Sigma, USA) $(10 \mathrm{mM}), 2.5 \mathrm{~mL}$ ferric chloride hexahydrate $\left(\mathrm{FeCl}_{3} \cdot 6 \mathrm{H}_{2}\right)$ solution (Merck, USA) $(20 \mathrm{mM})$ and acetate buffer (Merck, Germany) (300 mM; pH3.6) at a ratio of 1:1:30. Forty microlitres of ginger extract, natural product extract or control at a final concentration of $0,10,20,50$, $100,200,500$, or $1000 \mu \mathrm{gmL}^{-1}$ was mixed with $1.2 \mathrm{~mL}$ of FRAP reagent. The solution was incubated for $10 \mathrm{~min}$. The absorbance was measured at $593 \mathrm{~nm}$ by a Enspire Multimode Plate Reader (Perkin Elmer, Singapore). The antioxidant potential of the sample was determined by using a standard curve of ferrous sulphate $\left(\mathrm{FeSO}_{4} \cdot 7 \mathrm{H}_{2} \mathrm{O}\right)$ (Sigma, USA). 


\section{PREPARATION OF MYOBLAST CELLS IN CULTURE}

Primary human myoblast cells were purchased from Lonza (Walkersville, MD, USA) and cultured in complete culture media (CCM), skeletal muscle basal medium supplemented with human epidermal growth factor, foetal bovine serum, dexamethasone, L-glutamine, and gentamicin sulphate/amphotericin B (Lonza, MD, USA). Cells were cultured at $37{ }^{\circ} \mathrm{C}$ in a humid atmosphere containing $5 \% \mathrm{CO}_{2}$. The cells then underwent serial passaging until they reached the senescence stage. For each passage, the number of population doublings (PD) was calculated as $\log (\mathrm{N} / \mathrm{n}) / \log 2$, where $N$ indicates the number of cells at the time of passaging and $n$ was the number of cells at the seeding stage. The cells were divided into three groups: the young group $(\mathrm{PD}<15)$, presenescent group $(15<\mathrm{PD}>20)$ and senescent group (PD $>20)$ (Tan et al. 2021).

\section{MTS ASSAY FOR THE DETERMINATION OF CELL VIABILITY}

Cell viability was determined by a 3-(4,5-dimethylthiazol2-yl)-5-(3-carboxymethoxyphenyl)-2-(4-sulfonyl)2H-tetrazolium (MTS) calorimetric assay. The stock solutions of the ginger extracts GE1 and GE2 were freshly prepared in water at a concentration of $10 \mathrm{mgmL}^{-1}$. The stock solutions were kept for no more than one month at $-20{ }^{\circ} \mathrm{C}$. Both ginger extracts were serially diluted with complete culture medium (CCM) to concentrations of $0,10,20,30,50,100,200,300,500$, and $1000 \mu \mathrm{gmL}^{-1}$. Myoblast cells were plated at a density of $2 \times 10^{4}$ in 96well plates before incubation overnight. The medium was then exchanged with the new medium, which contained different concentrations of GE1 or GE2, and the cells were incubated in $5 \% \mathrm{CO}_{2}$ at $37^{\circ} \mathrm{C}$ for $24 \mathrm{~h}$. After $24 \mathrm{~h}$ of incubation, the media containing either GE1 or GE2 were replaced with new CCM prior to the MTS assay. Then, 20 $\mu \mathrm{L}$ MTS reagent (Promega, USA) was added, and the plate was incubated for another $2 \mathrm{~h}$. The value of the absorbance of MTS was measured at $490 \mathrm{~nm}$ by an Enspire Multimode Plate Reader (Perkin Elmer, Singapore).

\section{STATISTICAL ANALYSIS}

Each experiment was performed three times, and the data were recorded as the mean \pm standard deviation. The significant differences in the DPPH assay, FRAP assay and cell viability assay were analysed by one-way ANOVA. Comparisons between groups were made by a post hoc Tukey test. The analysis was carried out by using SPSS software version 20 , and $p<0.05$ was considered to indicate a significant difference.

\section{RESULTS AND DISCUSSION}

\section{ANTIOXIDANT PROPERTIES}

From the ultrahigh-performance liquid chromatography (UHPLC) results, both GE1 and GE2 were found to contain 6-gingerol and 6-shogaol as active compounds (Table 1). Figure 1 shows the DPPH scavenging activities of the ginger extracts GE1 and GE2 and the other natural product extracts. The DPPH radical scavenging activity increased with increasing concentrations of all extracts. The order of the DPPH scavenging activities was as follows: Vitamin $\mathrm{C}>\mathrm{TRF}>\alpha$-Tocopherol $>$ NAC $>$ Ficus deltoidea $>$ BHT $>$ Centella asiatica $>$ GE2 $>$ GE1 $>$ Moringa oleifera $>$ Kelulut honey. Interestingly, as shown in Figure 1, there was a significant difference in the DPPH scavenging activities between GE1 and GE2 at concentrations of $500 \mu \mathrm{g} / \mathrm{mL}$ and $1000 \mu \mathrm{gmL}^{-1}(p<0.05)$.

Figure 2 illustrates the FRAP activities of GE1, GE2 and the other natural product extracts. The FRAP activities increased with increasing concentrations of all the extracts. The order of the mean FRAP activity value was as follows: NAC $>\alpha$-Tocopherol $>$ BHT $>$ TRF $>$ Ficus deltoidea $>$ Moringa oleifera $>$ GE2 $=$ GE1 $>$ Centella asiatica $>$ Kelulut honey. However, no significant difference was observed in the FRAP activities between GE 1 and GE 2 at all concentrations used in the study.

In this study, DPPH scavenging activity assays and FRAP activity assays were performed to evaluate the antioxidant properties of 6-gingerol and 6-shogaol in these two types of Malaysian ginger extracts as well as those of other active compounds in the selected natural product extracts. In the DPPH assay, the antioxidant agent present in the two bioactive components (gingerol and shogoal) and in the other studied extracts scavenged the DPPH free radical by donating hydrogen, which contributed to the formation of the nonradical form of DPPH (Kedare \& Singh 2011). The DPPH free radical is an organic nitrogen free radical that is characterised by a deep purple colour. Therefore, during the assay, the colour changed from purple to yellow. However, the FRAP assay was performed based on the reducing power of the antioxidants in the studied compounds. The determined antioxidant property reduced the ferric ion $\left(\mathrm{Fe}^{3+}\right)$ to the ferrous ion $\left(\mathrm{Fe}^{2+}\right)$, which resulted in the formation of a blue complex ( $\mathrm{Fe}^{2+} / \mathrm{TPTZ}$ ) (Gupta 2015). The increase in FRAP activity indicated an increase in antioxidant capacity, as the FRAP assay result was based on the reduction of ferric 
ions. This is because antioxidants are reducing agents that can donate a single electron or hydrogen for reduction.

Based on the findings of this study, both types of Malaysian ginger extracts, which contain both gingerol and shogaol, exhibited higher levels of antioxidant activity than Moringa oleifera and Kelulut honey but lower levels of antioxidant activity than vitamin C, NAC, TRF, $\alpha$-tocopherol, Ficus deltoidea, BHT, and Centella asiatica. A previous study carried out by Nadeem et al. (2012) reported that ginger exhibited higher antioxidant activity than cumin extract, which was correlated with its total phenolic content. Another study performed by El-Ghorab et al. (2010) reported that in DPPH and FRAP assays, cumin essential oil displayed the highest antioxidant activity, followed by dried ginger essential oil and fresh ginger essential oil. Ginger also showed higher DPPH and FRAP activities than turmeric (Maizura et al. 2011). However, Misbah et al. (2013) found that the combination of ginger and turmeric powder showed higher free radical scavenging activity than the individual extracts of ginger and turmeric powder. In another study, ginger extract demonstrated better antioxidant properties than garlic, onion, thyme, aloe vera, mint, and oak (Abdul Qadir et al. 2017). This was related to the extraction efficiency of these components. Conversely, ginger and Indian gooseberry (Phyllanthus emblica officinalis) extracts showed the same range of total antioxidant and scavenging capacity but different functional effects (Kulsum et al. 2018). Ginger has shown less selective antiproliferative effects than Indian gooseberry extract.

The findings of our study also showed that the ginger extract GE2 had higher anti-radical activity than GE1 at high concentrations (500 and $\left.1000 \mu \mathrm{gmL}^{-1}\right)$. The UHPLC analysis showed that GE2 contains more 6-shogaol and less 6-gingerol than GE1, which contains less 6-shogoal but more 6-gingerol than GE2. These results are in accordance with those of a previous study that showed that 6-shogaol scavenges the DPPH radical more effectively than 6-gingerol (Dugasani et al. 2010; Guo et al. 2014).

Our results also showed that the free radical scavenging activities of the ginger extracts GE1 and GE2 increased with increasing concentration. This difference may be related to the composition of the extracts, which showed different percentages of 6-gingerol and 6-shogoal. Furthermore, 6-gingerol and 6-shogoal have different chemical structures, which may also contribute to the different antioxidant properties. A previous study reported that the conjugation of the $\alpha, \beta$-unsaturated ketone skeleton in the chemical structure of 6-shogaol resulted in 6-shogaol having higher efficacy and potency than 6-gingerol in terms of its anti-inflammatory, anticancer, anti-emetic, and antioxidant activities (Kou et al. 2018).

The extraction method used for ginger also affects its antioxidant properties (Ho et al. 2018). Rigane et al. (2018) demonstrated that the methanol extraction method produced ginger extract with higher antioxidant activity compared to other extraction methods. This observation was supported by a previous study performed by Tohma et al. (2017). It has been shown that the ethanolic extract of ginger displayed higher $\mathrm{Fe}^{2+}$ reducing power than the aqueous extract of ginger. The higher antioxidant activity in the alcohol extract may be due to the high polarity of alcohol, which allows the accumulation of antioxidant compounds in the extract.

The condition of the ginger also affects the antioxidant activity. Nadeem et al. (2012) reported that dried ginger samples result in a higher percentage of inhibition in the FRAP assay than fresh ginger, which showed that the dried ginger had high antioxidant activity. The antioxidant compounds in dried ginger might undergo an oxidation process that contributes to the high antioxidant activity. This was reinforced by a previous finding that demonstrated that fresh ginger had the lowest antioxidant activity compared to dried ginger, carbonized ginger, and stir-fried ginger ( $\mathrm{Li}$ et al. 2016). It has been suggested that the antioxidant activity of ginger is correlated with the total phenolic content. A previous study showed that the antioxidant activity was linearly proportional to the total phenolic content of ginger (Ghasemzadeh et al. 2016).

\section{CELL VIABILITY ASSAY}

Figures 3 and 4 show the percentages of viable myoblast cells (young, pre-senescent and senescent myoblasts) after incubation with GE1 and GE2, respectively, at various concentrations $\left(0-1000 \mu \mathrm{gmL}^{-1}\right)$ for $24 \mathrm{~h}$. The percentage of viable young myoblasts was significantly increased after GE1 treatment at concentrations of 10 - $1000 \mu \mathrm{gmL}^{-1}(p<0.05)$, as displayed in Figure 3(A). For pre-senescent myoblasts, there was no significant difference observed in cell viability after treatment with GE1 (Figure 3(B)). Moreover, the percentage of viable senescent myoblasts treated with GE1 was significantly increased at concentrations of $200-1000 \mu \mathrm{gmL}^{-1}$ (Figure $3(\mathrm{C}))$. For GE2 treatment, there was a significant increase $(p<0.05)$ in the percentage of viable young myoblasts treated with GE2 at concentrations of $100-1000 \mu \mathrm{gmL}^{-1}$, as shown in Figure 4(A). Figure 4(B) shows that there was no significant difference in presenescent myoblasts treated with GE2. For senescent myoblasts treated with 
100 - $1000 \mu \mathrm{gmL}^{-1} \mathrm{GE} 2$, a significant difference $(p<0.05)$ was observed, as shown in Figure 4(C).

Cell viability was assessed by an MTS calorimetric assay to determine the effect of various concentrations of GE1 and GE2, which contain different percentages of 6-gingerol and 6-shogaol, on the percentage of viable myoblast cells in culture. The principle of this assay was based on the conversion of tetrazolium salt by succinate dehydrogenase into insoluble purple formazan, which reflected mitochondrial activity (Ahmad et al. 2006). The viability of cells is indicated by the amount of formazan produced. Myoblasts of three different ages (young, presenescent and senescent) were used in this study. The effect of GE1 and GE2 on cell proliferation was observed. Our results showed that the percentage of viable cells was increased after both GE1 and GE2 treatments. Both young and senescent myoblasts showed a similar pattern of increase in cell viability with increasing concentrations of the ginger extracts. Our findings also showed that the cell viability gradually increased in a dose-dependent manner, and no toxicity was observed at the concentrations of ginger extract used in this study. The findings of this study are summarised in Figure 5.

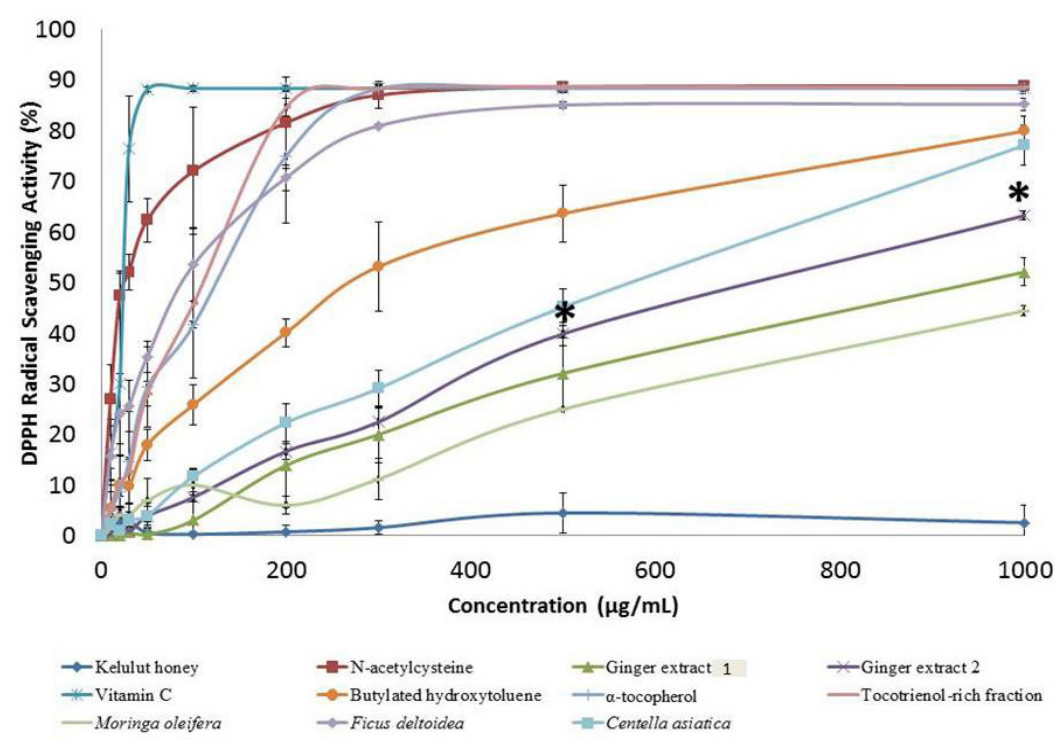

FIGURE 1. DPPH scavenging activities of ginger extract 1 (GE1), ginger extract 2 (GE2), the natural product extracts and the controls. *p $<0.05$ compared to ginger extract 1

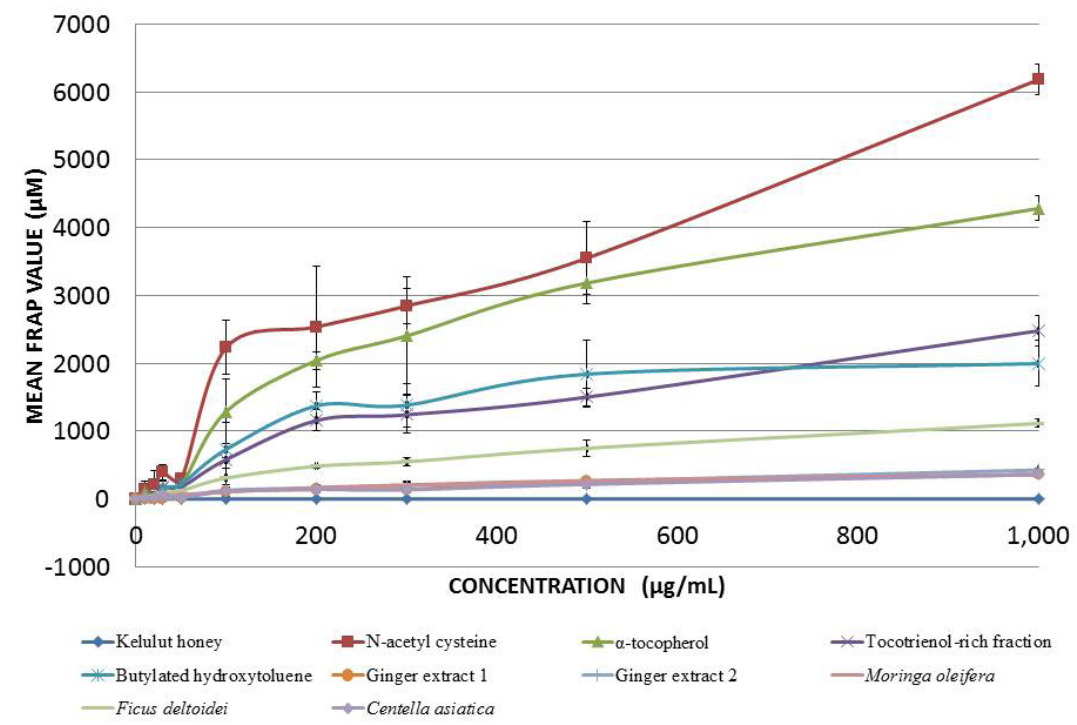

FIGURE 2. FRAP activities of ginger extract 1 (GE1), ginger extract 2 (GE2), the natural product extracts and controls 

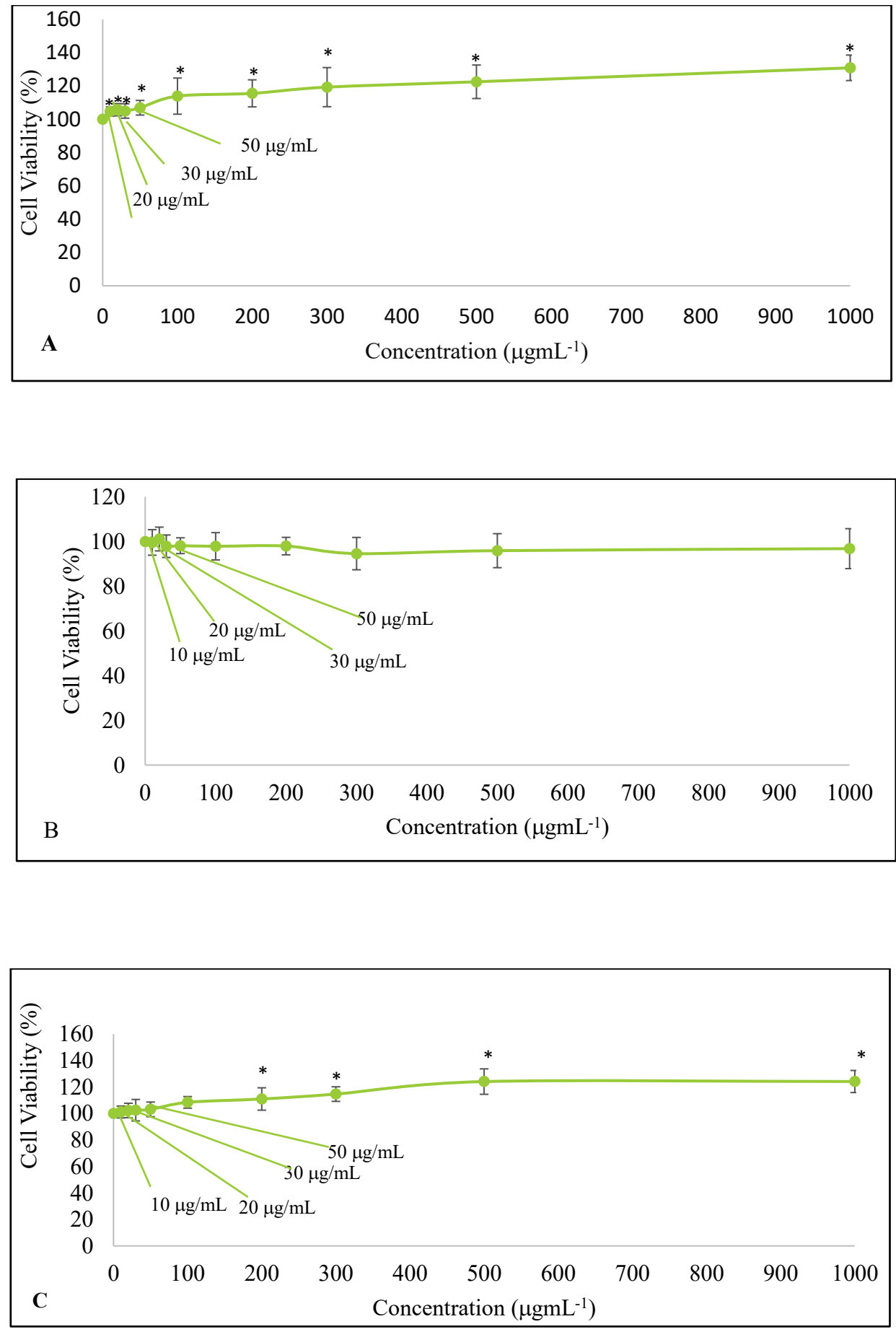

FIGURE 3. Percentage of viable young (A), presenescent (B) and senescent (C) myoblasts after incubation with ginger extract $1(\mathrm{GE} 1)$. ${ }^{*} \mathrm{P}<0.05$ compared to 0 $\mu \mathrm{gmL}^{-1}$. Data are expressed as the means $\pm \mathrm{SD}(\mathrm{N}=3)$ 

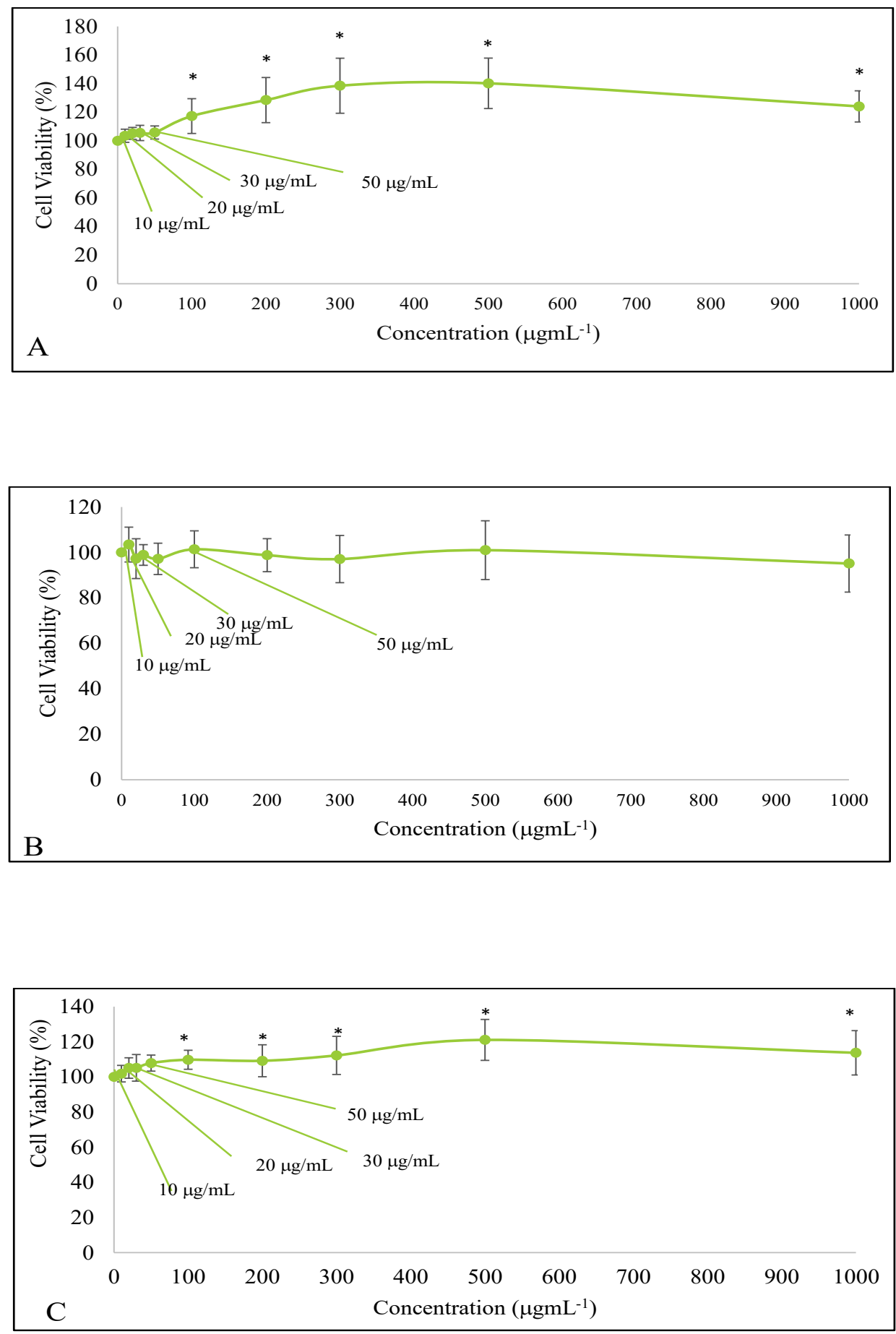

FIGURE 4. Percentage of viable young (A), presenescent (B) and senescent (C) myoblasts after incubation with ginger extract 2 (GE2). $* p<0.05$ compared to 0 $\mu \mathrm{gmL}^{-1}$. Data are expressed as the means $\pm \mathrm{SD}(\mathrm{N}=3)$ 


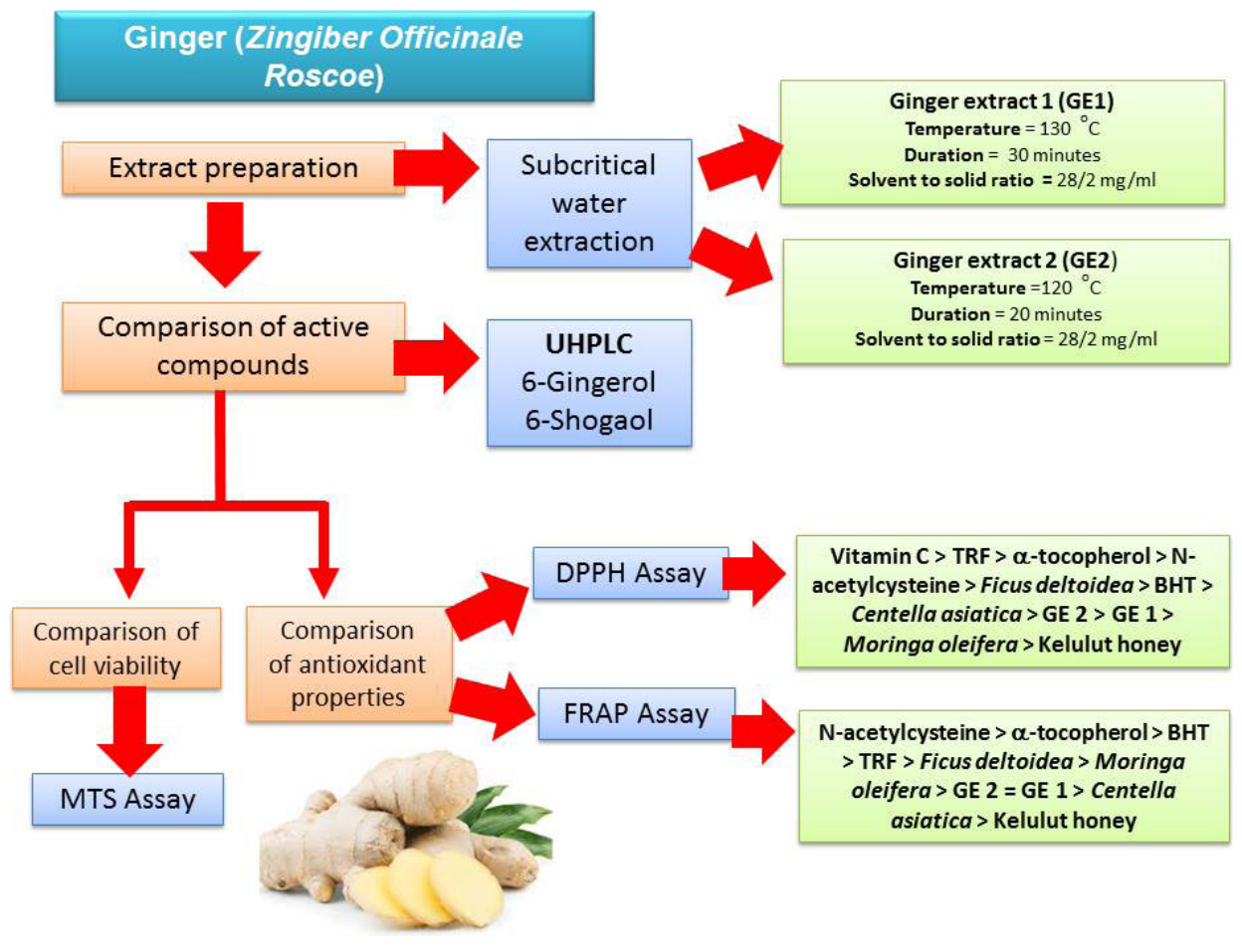

FIGURE 5. Summary of the findings

TABLE 1. Concentrations of 6-gingerol and 6-shogaol in ginger extract 1 (GE1) and ginger extract 2 (GE2) for the intra-day and inter-day assays

\begin{tabular}{lcccc}
\hline \multirow{2}{*}{ Compound } & \multicolumn{2}{c}{ 6-Gingerol } & \multicolumn{2}{c}{ 6-Shogoal } \\
\cline { 2 - 5 } & Intra-day & Inter-day & Intra-day & Inter-day \\
\hline Concentration in GE1 $\left(\mu \mathrm{gmL}^{-1}\right)$ & $289.531 \pm 2.887$ & $266.033 \pm 25.433$ & $15.466 \pm 0.271$ & $16.333 \pm 4.124$ \\
Concentration in GE2 $\left(\mu \mathrm{gmL}^{-1}\right)$ & $181.257 \pm 1.080$ & $167.044 \pm 18.211$ & $63.425 \pm 0.239$ & $55.943 \pm 9.620$ \\
\hline
\end{tabular}

\section{CONCLUSION}

Both types of Malaysian Zingiber officinale Roscoe extracts possessed comparable antioxidant properties and demonstrated the ability to reduce reactive oxygen species, indicating their potential for ameliorating oxidative stress-related diseases in addition to their lack of cytotoxicity toward cells and promotion of cell viability.

\section{ACKNOWLEDGEMENTS}

We would like to thank Associate Professor Dr Norliza Muhammad from the Department of Pharmacology,
Faculty of Medicine UKM, for the gift of Ficus deltoidea and the Centella asiatica standardised extract. This study was supported by Universiti Kebangsaan Malaysia Grant AP-2017-009/3.

\section{REFERENCES}

Abdul Qadir, M., Shahzadi, S.K., Bashir, A., Munir, A. \& Shahzad, S. 2017. Evaluation of phenolic compounds and antioxidant and antimicrobial activities of some common herbs. International Journal of Analytical Chemistry 2017 3475738 . 
Abrahim, N.N., Abdul-Rahman, P.S. \& Aminudin, N. 2018. The antioxidant activities, cytotoxic properties, and identification of water-soluble compounds of Ficus deltoidea leaves. Journal of Life \& Environmental Sciences 6: e5694.

Ahmad, N., Sulaiman, S., Mukti, N.A., Murad, N.A., Hamid, N.A.A. \& Yusof, Y.A.M. 2006. Effects of ginger extract (Zingiber officinale Roscoe) on antioxidant status of hepatocarcinoma induced rats. Malaysian Journal of Biochemistry and Molecular Biology 14: 7-12.

Ahmed, K., Shaheen, G. \& Asif, H. 2011. Zingiber officinale Roscoe (pharmacological activity). Journal of Medicinal Plants Research 5(3): 344-348.

Al-Amin, Z.M., Thomson, M., Al-Qattan, K.K., PeltonenShalaby, R. \& Ali, M. 2006. Anti-diabetic and hypolipidaemic properties of ginger (Zingiber officinale) in streptozotocininduced diabetic rats. British Journal of Nutrition 96(4): 660-666.

Ariffin, F., Heong Chew, S., Bhupinder, K., Karim, A.A. \& Huda, N. 2011. Antioxidant capacity and phenolic composition of fermented Centella asiatica herbal teas. Journal of The Science of Food and Agriculture 91(15): 2731-2739.

Chakotiya, A.S., Tanwar, A., Narula, A. \& Sharma, R.K. 2017. Zingiber officinale: Its antibacterial activity on Pseudomonas aeruginosa and mode of action evaluated by flow cytometry. Microbial Pathogenesis 107: 254-260.

Dugasani, S., Pichika, M.R., Nadarajah, V.D., Balijepalli, M.K., Tandra, S. \& Korlakunta, J.N. 2010. Comparative antioxidant and anti-inflammatory effects of [6]-gingerol, [8]-gingerol, [10]-gingerol and [6]-shogaol. Journal of Ethnopharmacology 127(2): 515-520.

El-Ghorab, A.H., Nauman, M., Anjum, F.M., Hussain, S. \& Nadeem, M. 2010. A comparative study on chemical composition and antioxidant activity of ginger (Zingiber officinale) and cumin (Cuminum cyminum). Journal of Agricultural and Food Chemistry 58(14): 8231-8237.

Ezzat, S.M., Ezzat, M.I., Okba, M.M., Menze, E.T. \& AbdelNaim, A.B. 2018. The hidden mechanism beyond ginger (Zingiber officinale Rosc.) potent in vivo and in vitro antiinflammatory activity. Journal of Ethnopharmacology 214: 113-123.

Garcia, E.J., Oldoni, T.L.C., Alencar, S.M.D., Reis, A., Loguercio, A.D. \& Grande, R.H.M. 2012. Antioxidant activity by DPPH assay of potential solutions to be applied on bleached teeth. Brazilian Dental Journal 23(1): 22-27.

Ghasemzadeh, A., Jaafar, H. \& Rahmat, A. 2016. Variation of the phytochemical constituents and antioxidant activities of Zingiber officinale Var. Rubrum Theilade associated with different drying methods and polyphenol oxidase activity. Molecules 21(6): 780.

Guo, J., Wu, H., Du, L., Zhang, W. \& Yang, J. 2014. Comparative antioxidant properties of some gingerols and shogaols, and the relationship of their contents with the antioxidant potencies of fresh and dried ginger (Zingiber officinale Roscoe). Journal of Agricultural Science and Technology 16: 1063-1072.
Gupta, D. 2015. Methods for determination of antioxidant capacity: A review. International Journal of Pharmaceutical Sciences and Research 6(2): 546-566.

Habib, S.H.M., Makpol, S., Hamid, N.A.A., Das, S., Ngah, W.Z.W. \& Yusof, Y.A.M. 2008. Ginger extract (Zingiber officinale) has anti-cancer and anti-inflammatory effects on ethionine-induced hepatoma rats. Clinics 63(6): 807-813.

Ho, L.H., Ramli, N.F., Tan, T.C., Muhamad, N. \& Haron, M.N. 2018. Effect of extraction solvents and drying conditions on total phenolic content and antioxidant properties of watermelon rind powder. Sains Malaysiana 47(1): 99-107.

Hussein, U.K., Hassan, N.E.H.Y., Elhalwagy, M.E., Zaki, A.R., Abubakr, H.O., Nagulapalli Venkata, K.C., Jang, K.Y. \& Bishayee, A. 2017. Ginger and propolis exert neuroprotective effects against monosodium glutamateinduced neurotoxicity in rats. Molecules 22(11): 1928.

Jolad, S.D., Lantz, R.C., Solyom, A.M., Chen, G.J., Bates, R.B. \& Timmermann, B.N. 2004. Fresh organically grown ginger (Zingiber officinale): Composition and effects on LPS-induced PGE2 production. Phytochemistry 65(13): 1937-1954

Kedare, S.B. \& Singh, R.P. 2011. Genesis and development of DPPH method of antioxidant assay. Journal of Food Science and Technology 48(4): 412-422.

Kishore, R.K., Halim, A.S., Syazana, M.N. \& Sirajudeen, K.N.S. 2011. Tualang honey has higher phenolic content and greater radical scavenging activity compared with other honey sources. Nutrition Research 31(4): 322-325.

Kou, X., Wang, X., Ji, R., Liu, L., Qiao, Y., Lou, Z., Ma, C., Li, S., Wang, H. \& Ho, C.T. 2018. Occurrence, biological activity and metabolism of 6-shogaol. Food and Function 9(3): 1310-1327.

Kulkarni, R.A. \& Deshpande, A.R. 2016. Anti-inflammatory and antioxidant effect of ginger in tuberculosis. Journal of Complementary and Integrative Medicine 13(2): 201-206.

Kulsum, S., Suresh, A. \& Mehta, A. 2018. Correlation of antioxidant and antiproliferative activity of amla and ginger. Asian Journal of Pharmaceutical and Clinical Research 11(8): 263-269.

Li, Y., Hong, Y., Han, Y., Wang, Y. \& Xia, L. 2016. Chemical characterization and antioxidant activities comparison in fresh, dried, stir-frying and carbonized ginger. Journal of Chromatography B 1011: 223-232.

Liju, V.B., Jeena, K. \& Kuttan, R. 2015. Gastroprotective activity of essential oils from turmeric and ginger. Journal of Basic and Clinical Physiology and Pharmacology 26(1): 95-103.

Mahluji, S., Ostadrahimi, A., Mobasseri, M., Attari, V.E. \& Payahoo, L. 2013. Anti-inflammatory effects of Zingiber officinale in type 2 diabetic patients. Advanced Pharmaceutical Bulletin 3(2): 273-276.

Maizura, M., Aminah, A. \& Wan Aida, W.M. 2011. Total phenolic content and antioxidant activity of kesum (Polygonum minus), ginger (Zingiber officinale) and turmeric (Curcuma longa) extract. International Food Research Journal 18(2): 526-531. 
Meng, S.J. \& Yu, L.J. 2010. Oxidative stress, molecular inflammation and sarcopenia. International Journal of Molecular Sciences 11(4): 1509-1526.

Misbah, H., Aziz, A.A. \& Aminudin, N. 2013. Antidiabetic and antioxidant properties of Ficus deltoidea fruit extracts and fractions. BMC Complementary and Alternative Medicine 13(1): 118

Mozaffari-Khosravi, H., Naderi, Z., Dehghan, A., Nadjarzadeh, A. \& Fallah Huseini, H. 2016. Effect of ginger supplementation on proinflammatory cytokines in older patients with osteoarthritis: Outcomes of a randomized controlled clinical trial. Journal of Nutrition in Gerontology and Geriatrics 35(3): 209-218.

Nadeem, M., Hussain, S., El-Ghorab, A., Anjum, F. \& Nauman, M. 2012. Antioxidant activity of ginger (Zingiber officinale) and cumin. Journal of Agricultural and Food Chemistry 58: 8231-8237.

Pakade, V., Cukrowska, E. \& Chimuka, L. 2013. Comparison of antioxidant activity of Moringa oleifera and selected vegetables in South Africa. South African Journal of Science 109(3-4): 1-5.

Park, M., Bae, J. \& Lee, D.S. 2008. Antibacterial activity of [10] -gingerol and [12] -gingerol isolated from ginger rhizome against periodontal bacteria. Phytotherapy Research: An International Journal Devoted to Pharmacological and Toxicological Evaluation of Natural Product Derivatives 22(11): 1446-1449.

Pashaei-Asl, R., Pashaei-Asl, F., Gharabaghi, P.M., Khodadadi, K., Ebrahimi, M., Ebrahimie, E. \& Pashaiasl, M. 2017. The inhibitory effect of ginger extract on ovarian cancer cell line; Application of systems biology. Advanced Pharmaceutical Bulletin 7(2): 241-249.

Pourreza, N. 2013. Phenolic compounds as potential antioxidant. Jundishapur Journal of Natural Pharmaceutical Products 8(4): 149-150.

Rahman, M., Hossain, S., Rahaman, A., Fatima, N., Nahar, T., Uddin, B. \& Basunia, M.A. 2013. Antioxidant activity of Centella asiatica (Linn.) urban: Impact of extraction solvent polarity. Journal of Pharmacognosy and Phytochemistry 1(6): 27-32.

Ramalingam, M. \& Kim, S.J. 2012. Reactive oxygen/ nitrogen species and their functional correlations in neurodegenerative diseases. Journal of Neural Transmission 119(8): 891-910

Rigane, G., Mnif, S. \& Salem, R.B. 2018. One step purification of 6-shogaol from Zingiber officinale Rosco, a phenolic compound having a high effectiveness against bacterial strains. Revue Roumaine de Chimie 63(1): 5-10.

Saha, A., Blando, J., Silver, E., Beltran, L., Sessler, J. \& DiGiovanni, J. 2014. 6-Shogaol from dried ginger inhibits growth of prostate cancer cells both in vitro and in vivo through inhibition of STAT3 and NF- $\mathrm{KB}$ signaling. Cancer Prevention Research 7(6): 627-638.

Shimoda, H., Shan, S.J., Tanaka, J., Seki, A., Seo, J.W., Kasajima, N., Tamura, S., Ke, Y. \& Murakami, N. 2010. Anti-inflammatory properties of red ginger (Zingiber officinale var. Rubra) extract and suppression of nitric oxide production by its constituents. Journal of Medicinal Food 13(1): 156-162.

Shirin-Adel, P.R. \& Prakash, J. 2010. Chemical composition and antioxidant properties of ginger root (Zingiber officinale) Journal of Medicinal Plants Research 4(24): 2674-2679.

Si, W., Chen, Y.P., Zhang, J., Chen, Z.Y. \& Chung, H.Y. 2018. Antioxidant activities of ginger extract and its constituents toward lipids. Food Chemistry 239: 1117-1125.

Suzuki, S., Fujita, N., Hosogane, N., Watanabe, K., Ishii, K., Toyama, Y., Takubo, K., Horiuchi, K., Miyamoto, T., Nakamura, M. \& Matsumoto, M. 2015. Excessive reactive oxygen species are therapeutic targets for intervertebral disc degeneration. Arthritis Research and Therapy 17(1): $1-17$

Tan, C.M., Najib, N.A.M., Suhaimi, N.F., Halid, N.A., Cho, V.V., Abdullah, S.I., Ismail, M.Z., Khor, S.C., Jaafar, F. \& Makpol, S. 2021. Modulation of Ki67 and myogenic regulatory factor expression by tocotrienol-rich fraction ameliorates myogenic program of senescent human myoblasts. Archives of Medical Science 17(3): 1-12.

Tanaka, K., Arita, M., Sakurai, H., Ono, N. \& Tezuka, Y. 2015. Analysis of chemical properties of edible and medicinal ginger by metabolomics approach. Biomed Research International 2015: 671058

Tohma, H., Gülçin, İ., Bursal, E., Gören, A.C., Alwasel, S.H \& Köksal, E. 2017. Antioxidant activity and phenolic compounds of ginger (Zingiber officinale Rosc.) determined by HPLC-MS/MS. Journal of Food Measurement and Characterization 11(2): 556-566.

Valera, M.C., Cardoso, F.G.D.R., Maekawa, L.E., Camargo, C.H.R., De Oliveira, L.D. \& Carvalho, C.A.T. 2015. In vitro antimicrobial and anti-endotoxin action of Zingiber officinale as auxiliary chemical and medicament combined to calcium hydroxide and chlorhexidine. Acta Odontologica Scandinavica 73(7): 556-561.

Van Breemen, R.B., Tao, Y. \& Li, W. 2011. Cyclooxygenase-2 inhibitors in ginger (Zingiber officinale). Fitoterapia 82(1): 38-43.

Wang, Y., Yu, H., Zhang, X., Feng, Q., Guo, X., Li, S., Li, R., Chu, D. \& Ma, Y. 2017. Evaluation of daily ginger consumption for the prevention of chronic diseases in adults: A crosssectional study. Nutrition 36: 79-84.

Waris, G. \& Ahsan, H. 2006. Reactive oxygen species: Role in the development of cancer and various chronic conditions. Journal of Carcinogenesis 5: 14.

Wright, R.J., Lee, K.S., Hyacinth, H.I., Hibbert, J.M., Reid, M.E., Wheatley, A.O. \& Asemota, H.N. 2017. An investigation of the antioxidant capacity in extracts from Moringa oleifera plants grown in Jamaica. Plants 6(48): 1-8.

Yasmin Anum, M.Y., Shahriza, Z.A., Looi, M.L., Shafina Hanim, M.H., Harlianshah, H., Noor Aini, A.H., Suzana, M. \& Wan Zurinah, W.N. 2008. Ginger extract (Zingiber officinale Roscoe) triggers apoptosis in hepatocarcinogenesis induced rats. Medicinal Health 3(2008): 263-274. 
Nur Fatin Nabilah Mohd Sahardi, Faizul Jaafar, Siti Nor Asyikin Zakaria, Jen Kit Tan \& Suzana Makpol*

Department of Biochemistry

Faculty of Medicine

Universiti Kebangsaan Malaysia

HCTM, Jalan Yaacob Latif

56000 Cheras, Kuala Lumpur, Federal Territory

Malaysia

\section{Mariam Firdhaus Mad Nordin}

Department of Chemical Process Engineering

Universiti Teknologi Malaysia, Kuala Lumpur

Jalan Sultan Yahya Petra

54100 Kuala Lumpur, Federal Territory

Malaysia
*Corresponding author; email: suzanamakpol@ppukm.ukm. edu.my

Received: 28 July 2020

Accepted: 25 September 2020 